\title{
A study of the effectiveness of calcined magnesite as a neutralizing agent for hydrochloric acid in the diet of sheep
}

\author{
By 'T. McNAMARA* AND J. L. L'ESTRANGE \\ Department of Agricultural Chemistry, University College Dublin, \\ Glasnevin, Dublin 9, Republic of Ireland
}

(Received 28 October I974-Accepted 7 Fanuary 1975)

\begin{abstract}
1. Five experimental diets were offered $a d l i b$. for $2 \mathrm{I}$ d to five sheep in a $5 \times 5$ Latin-square design experiment as follows: pelleted grass meal alone (control); pelleted grass meal plus hydrochloric acid $(470 \mathrm{mmol} / \mathrm{kg}$ dry matter (DM)); pelleted grass meal plus $470 \mathrm{mmol} \mathrm{HCl} / \mathrm{kg}$ $\mathrm{DM}$ and either an equivalent amount of calcined magnesite $(\mathrm{MgO})(235 \mathrm{mmol} / \mathrm{kg} \mathrm{DM})$ or twice the amount ( $470 \mathrm{mmol} \mathrm{MgO} / \mathrm{kg} \mathrm{DM}$ ); pelleted grass meal plus $470 \mathrm{mmol} \mathrm{MgO} / \mathrm{kg} \mathrm{DM}$.

2. $\mathrm{MgO}$ supplementation partly prevented the reduction in food intake caused by $\mathrm{HCl}$, being more effective at the low than at the high level. When fed alone, the high level of $\mathrm{MgO}$ had a slight adverse effect on food intake.

3. There was no significant treatment effect on either the $\mathrm{pH}$ or volatile fatty acid concentrations of rumen fluid. $\mathrm{MgO}$ supplementation was only slightly effective in preventing the metabolic acidosis caused by $\mathrm{HCl}$ supplementation, as indicated by blood and urine acid-base measurements.

4. With the MgO-supplemented diets, values for the faecal and urinary excretion of magnesium were approximately 70 and $10 \%$ respectively of $\mathrm{Mg}$ intake and were not significantly affected by $\mathrm{HCl}$ supplementation. For rumen fluid, the water-soluble $\mathrm{Mg}$ concentration as a percentage of the total $\mathrm{Mg}$ concentration was similar for each treatment, approximately $90 \%$. For faeces, the corresponding value was also similar for each treatment, approximately $30 \%$.

5. $\mathrm{MgO}$ supplementation altered the effect of dietary $\mathrm{HCl}$ on faecal calcium excretion and on the balance of $\mathrm{Ca}$, but did not alter its effect on urinary $\mathrm{Ca}$ excretion.

6. It is concluded that the beneficial effect of $\mathrm{MgO}$ supplementation on the intake of the $\mathrm{HCl}$-treated diet was related more to its influence on dietary $\mathrm{pH}$ than on conditions in the rumen or the acid-base balance of the sheep.
\end{abstract}

The feeding of neutralizing agents with silage preserved with mineral acids has long been recommended (Lepard, Page, Maynard, Rasmussen \& Savage, 1940). Calcium carbonate or limestone has been most widely used for this purpose, although in experiments with cattle it has been found to be only about half as effective as sodium bicarbonate (Brouwer, 1935; Mollgaard \& Thorbek, 1938; King, 1943). These workers were concerned mainly with preventing the metabolic acidosis induced by the silage preserved with mineral acids. King (1943), however, found that after adequate neutralization of the silage its consumption increased rapidly.

Calcined magnesite $(\mathrm{MgO})$ is widely used as a source of supplementary magnesium for cattle and sheep to prevent hypomagnesaemic tetany. The possibility of feeding $\mathrm{MgO}$ by incorporating it into silage was studied by Black (1966), who reported that at levels of $1 \cdot 5-2 \cdot 0 \mathrm{~g} / \mathrm{kg}$ herbage, it was beneficial, but at higher levels it caused undesirable side effects in both the silage and the animals eating it. $\mathrm{MgO}$ has also been found to be as effective as $\mathrm{NaHCO}_{3}$ for the maintenance of normal milk-fat

* Present address: The Valuation Office, Department of Finance, 6 Ely Place, Dublin 2, Republic of Ireland. 
Table I. Chemical composition ( $g / k g$ dry matter) of the pelleted grass meal given as the basal diet to sheep

\begin{tabular}{lrllr}
\multicolumn{2}{c}{ Proximate analysis } & \multicolumn{2}{c}{ Mineral content } \\
Crude protein & $\mathbf{1} 84$ & Calcium & $5 \cdot 8$ \\
Diethyl ether extract & 26 & Magnesium & $\mathrm{I} \cdot 3$ \\
Crude fibre & $\mathrm{I} 88$ & Sodium & $2 \cdot 4$ \\
Ash & $\mathrm{I} 29$ & Potassium & $\mathbf{2 8} \cdot \mathbf{2}$ \\
Nitrogen-free extract & 473 & Chloride & $\mathrm{I} 8 \cdot \mathbf{I}$
\end{tabular}

content for cows given low-roughage diets (Emery, Brown \& Bell, I965; Thomas \& Emery, 1966).

The widespread use of $\mathrm{MgO}$ in ruminant feeding, and also its much higher neutralizing value per unit weight than $\mathrm{CaCO}_{3}$ suggested that a study of the potential of $\mathrm{MgO}$ as a neutralizing agent for silage preserved with mineral acids or their acid salts might be useful. It was therefore decided to study the effect of $\mathrm{MgO}$ supplementation using sheep given a pelleted grass-meal diet containing supplementary hydrochloric acid. Its effect on food intake, fermentation in the rumen, dry matter (DM) digestibility and acid-base balance was determined. In addition, its effect on $\mathrm{Mg}$ solubility in rumen fluid and faeces and on $\mathrm{Mg}$ and $\mathrm{Ca}$ absorption and excretion was studied.

\section{EXPERIMENTAL}

Animals. The sheep used were 2-year-old Cheviot wethers, which were housed in metabolism cages throughout the experiment.

Treatments. Pelleted dried-grass meal, the composition of which is shown in Table I, was used as the basal diet. The pelleted grass meal was offered alone or supplemented with $\mathrm{HCl}$ and $\mathrm{MgO}$ as follows: basal only (control); basal plus $470 \mathrm{mmol} \mathrm{HCl} / \mathrm{kg} \mathrm{DM}$; basal plus $470 \mathrm{mmol} \mathrm{HCl} / \mathrm{kg}$ DM and equivalent amount of $\mathrm{MgO}$ (235 mmol $/ \mathrm{kg} \mathrm{DM}$ ); basal plus $470 \mathrm{mmol} \mathrm{HCl}$ plus $47^{\circ} \mathrm{mmol} \mathrm{MgO} / \mathrm{kg}$ DM; basal plus $470 \mathrm{mmol} \mathrm{MgO} / \mathrm{kg}$ DM. The $\mathrm{HCl}$ was added by pouring $300 \mathrm{ml} \mathrm{I} \cdot 4 \mathrm{M}-\mathrm{HCl}$ onto $2 \mathrm{~kg}$ pelleted grass meal in a plastic container which was shaken thoroughly to ensure an even mixture. In treatments without $\mathrm{HCl}$, distilled water $(150 \mathrm{ml} / \mathrm{kg}$ ) was added to the pelleted grass meal using the same procedure. The $\mathrm{MgO}$, which was a fine powder containing $800 \mathrm{~g}$ magnesium oxide $/ \mathrm{kg}$, was added to each $2 \mathrm{~kg}$ batch of diet after addition of the $\mathrm{HCl}$ or distilled water and was mixed by shaking the plastic container.

Procedure. The five treatments were given to five sheep in a $5 \times 5$ Latin-square design experiment. The diets were offered $a d l i b$. for $21 \mathrm{~d}$, followed by a $7 \mathrm{~d}$ recovery period when they were offered the control diet ad lib., before the next dietary treatment. Food intake was recorded daily and food residues were removed twice weekly. Distilled water was provided throughout the experiment and its intake recorded. Urine and faeces were collected and sampled using the procedures previously described (L'Estrange \& Murphy, 1972). Blood samples from each animal were taken from the jugular vein at regular intervals during the experiment. The sampling and storage procedures were those previously described by L'Estrange \& Murphy (1972). Rumen 
fluid samples were taken from each sheep at 14.00 hours on days 5 and 19 of each treatment period. The $\mathrm{pH}$ of whole rumen contents was measured immediately after sampling. The sample was then filtered through muslin cloth and stored at $2^{\circ}$ and mercuric chloride was added as a preservative.

Analytical methods. The procedures used for the analysis of DM content of food, $\mathrm{pH}$ of blood, urine and rumen fluid, total carbon dioxide concentration for plasma, base excess (BE) status of blood, volatile fatty acid (VFA) content of rumen fluid, $\mathrm{Ca}$ and $\mathrm{Mg}$ contents of serum and of ashed food, faeces and urine samples, were those previously described by L'Estrange \& Murphy (I972). Chloride contents of serum and urine and of $\mathrm{I} .6 \mathrm{M}$-nitric acid extracts of food and faeces were determined using the method previously described by L'Estrange \& McNamara (I975). Water-soluble Mg concentration for the rumen fluid was determined by adding $8 \mathrm{ml}$ water to $2 \mathrm{ml}$ rumen fluid, which was then centrifuged at $2000 \mathrm{rev} . / \mathrm{min}$ for ro min and the $\mathrm{Mg}$ content of the supernatant fraction was estimated. Water-soluble Mg concentration for the faeces was determined by adding $\mathrm{I} g$ fresh faeces to $10 \mathrm{ml}$ water, boiling for $5 \mathrm{~min}$ and after centrifugation estimating the $\mathrm{Mg}$ content of the supernatant fraction. Acid-soluble $\mathrm{Mg}$ concentration for the rumen fluid and faeces was determined by substituting I $\mathrm{M}-\mathrm{HCl}$ for water in the method described for the estimation of watersoluble $\mathrm{Mg}$.

\section{RESULTS}

Dietary $p H$. The $\mathrm{pH}$ of the pelleted grass meal (diluted $\mathrm{r}: 5(\mathrm{v} / \mathrm{v})$ with distilled water) was lowered from $5.8 \mathrm{r}$ to $3 \cdot 15$ by $\mathrm{HCl}$ supplementation. $\mathrm{MgO}$ supplementation of the diet containing $\mathrm{HCl}$ increased the $\mathrm{pH}$ of the diet to $4 \cdot 3^{8}$ and 4.78 at the low and high levels of $\mathrm{MgO}$ respectively. $\mathrm{MgO}$ supplementation of the basal diet (equivalent to the high level of $\mathrm{MgO}$ supplementation of the $\mathrm{HCl}$-containing diet) increased the $\mathrm{pH}$ to $6 \cdot 52$.

$D M$ intake. From day 7 to day 21 of the treatment period, voluntary DM intake was decreased by $\mathrm{HCl}$ supplementation without added $\mathrm{MgO}$ to approximately $66 \%$ of the value for the basal diet (control) (Table 2). $\mathrm{MgO}$ supplementation of the $\mathrm{HCl}$ containing diet increased DM intake to 84 and $75 \%$ of control value at the low and high $\mathrm{MgO}$ levels respectively; the increase was significant $(P<0.05)$ for the low level of $\mathrm{MgO}$ only. For the diet containing $\mathrm{MgO}$ at the high level, without supplementary $\mathrm{HCl}$, DM intake was reduced to $87 \%$ of the control value, this reduction was not significant $(P>0.05)$. For each treatment DM intake during the first $7 \mathrm{~d}$ of treatment (Table 2) was similar to that during the subsequent $\mathrm{i}_{4} \mathrm{~d}$, although the effect of $\mathrm{HCl}$ was not so great. During the $7 \mathrm{~d}$ recovery period DM intake increased rapidly to control values with no significant carry-over effects of treatment (Table 2).

Water intake and excretion. Daily water intake was not significantly affected by treatment $(P>0.05)$. Water intake/unit DM eaten (Table 2$)$ was significantly higher for the diet containing $\mathrm{HCl}$ without added $\mathrm{MgO}$ than for the control diet $(P<0.05)$, and was intermediate between those for the other treatments. Urine volume (Table 2) was significantly higher for the diet containing $\mathrm{HCl}$ and the low level of supplementary $\mathrm{MgO}$ than for the other treatments $(P<0.05)$. 


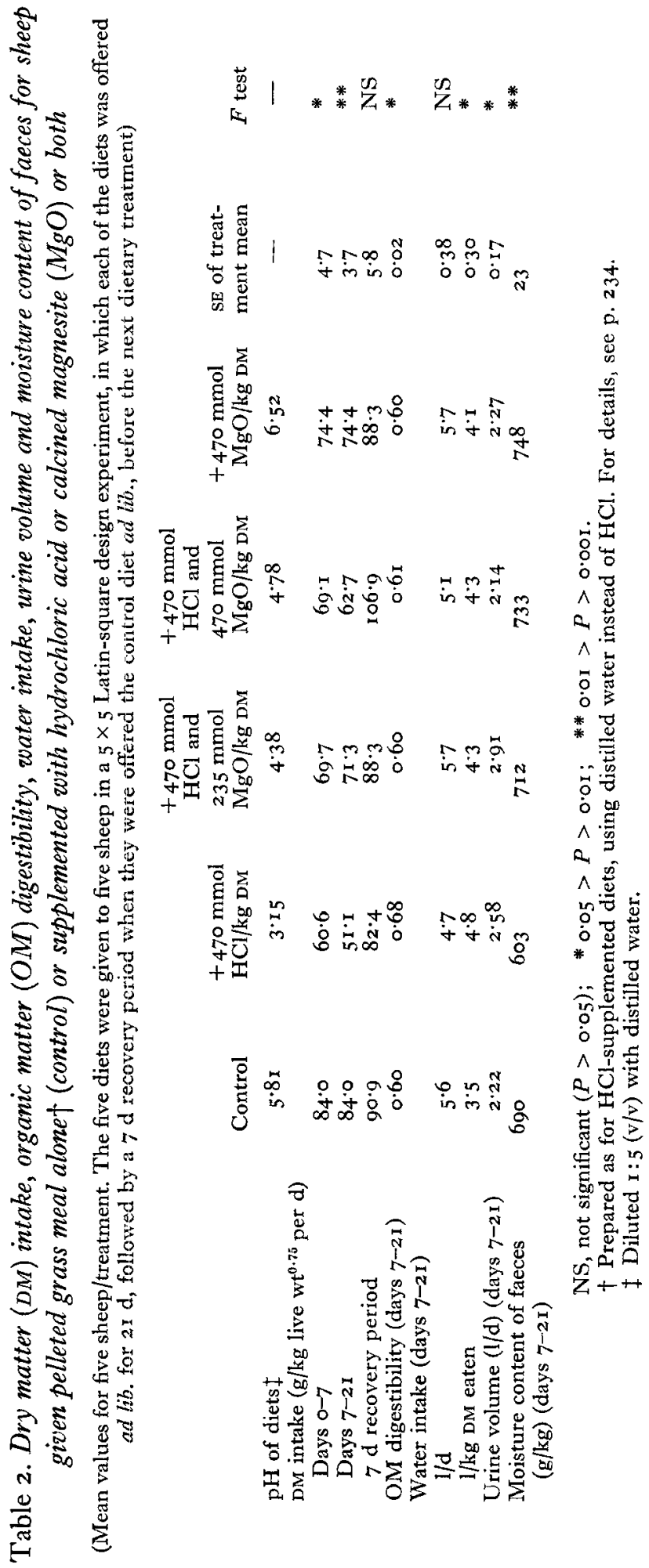


The moisture content of faeces ('Table 2) was significantly lower for the diet containing $\mathrm{HCl}$ without added $\mathrm{MgO}$ than for the other treatments $(P<0.0 \mathrm{I})$. $\mathrm{MgO}$ supplementation, particularly at the higher level (both with and without $\mathrm{HCl}$ ), increased the moisture content of faeces above the control value but the difference was not significant $(P>0.05)$. It may be noted that scouring was not observed in the sheep when they were given $\mathrm{MgO}$-supplemented diets.

Organic matter digestibility. Organic matter digestibility was significantly higher $(P<0.05)$ for the diet containing $\mathrm{HCl}$ without added $\mathrm{MgO}$ than for the other treatments, which had very similar values (Table 2 ).

$p H$ and VFA in rumen fluid. The $\mathrm{pH}$ of rumen fluid was lower, by about 0.2 units, for the diet containing $\mathrm{HCl}$ without added $\mathrm{MgO}$ than for the other treatments, but this difference was not significant $(P>0.05)$; the average value for all treatments was 6.72. There was no significant treatment effect on total VFA concentration, which averaged $86.3 \mathrm{mmol} / 1$ for all treatments. The molar proportions of individual VFA for rumen fluid were also not significantly affected by treatment; average values for acetic, propionic, isobutyric, butyric, isovaleric and valeric were $688,144,24 \cdot 2,107$, 27.8 and $10.8 \mathrm{mmol} / \mathrm{mol}$ respectively.

Acid-base balance. The diet containing $\mathrm{HCl}$ without added $\mathrm{MgO}$ significantly lowered plasma total $\mathrm{CO}_{2}$ concentration $(P<0.00 \mathrm{I})$ and blood $\mathrm{BE}$ status $(P<0.0 \mathrm{I})$ but did not significantly affect blood $\mathrm{pH}(P>0.05)$ (Table 3$)$. MgO supplementation of the diet containing $\mathrm{HCl}$ did not significantly affect blood $\mathrm{pH}$, plasma total $\mathrm{CO}_{2}$ concentration or blood BE status $(P>0.05)$ and, therefore, was not effective in preventing the metabolic acidosis caused by $\mathrm{HCl}$ in the diet.

For the urine, the diet containing $\mathrm{HCl}$ without added $\mathrm{MgO}$ significantly lowered $\mathrm{pH}$ and bicarbonate excretion and increased the excretion of ammonia-nitrogen and $\mathrm{Ca}$ (Table 3). When the $\mathrm{HCl}$-containing diet was supplemented with $\mathrm{MgO}$ there was no significant change in the effect of the $\mathrm{HCl}$ on urine $\mathrm{pH}$ or urinary $\mathrm{Ca}$ excretion but, at the high level of $\mathrm{MgO}$ supplementation, ammonia- $\mathrm{N}$ excretion was reduced and at both levels of $\mathrm{MgO}$, bicarbonate excretion was increased. The urine, which was alkaline when the sheep were given the pelleted grass meal alone, was not made more alkaline by $\mathrm{MgO}$ supplementation.

Minerals in serum. The serum $\mathrm{Mg}$ concentration was increased by $\mathrm{MgO}$ supplementation by about $0.08 \mathrm{mmol} / \mathrm{l}$, both with and without $\mathrm{HCl}$ supplementation, while the serum Ca concentration was not affected by treatment (Table 3).

Intake, excretion and balance of $\mathrm{Mg}$. While $\mathrm{MgO}$ supplementation resulted in a very large increase in $\mathrm{Mg}$ intake, the amount consumed was about $20 \%$ less than it would have been if the supplement had been eaten uniformly with the rest of the DM. This was due to a tendency for the supplement to fall to the bottom of the food container and accumulate in the food residue.

The metabolism of $\mathrm{Mg}$ was similar for both the control diet and the diet containing $\mathrm{HCl}$ without added $\mathrm{MgO}$; faecal $\mathrm{Mg}$ excretion was approximately the same as the intake, resulting in a small negative balance due to $\mathrm{Mg}$ excretion in the urine (Table 4 ). The metabolism of $\mathrm{Mg}$ for $\mathrm{MgO}$-supplemented diets was considerably different from that for the control diet. Over all, excretion in the faeces accounted for about $70 \%$ of 


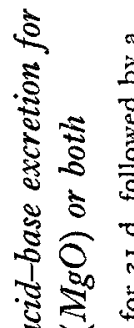

$$
\begin{aligned}
& \text { s }
\end{aligned}
$$$$
\text { ᄀ. }
$$

है

है

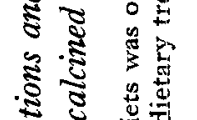

เป

हี :

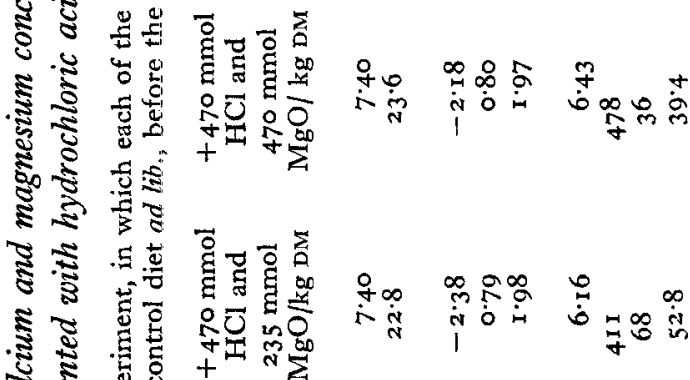

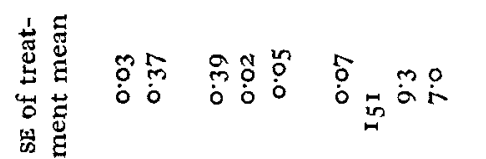

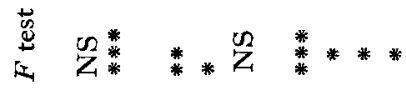

음

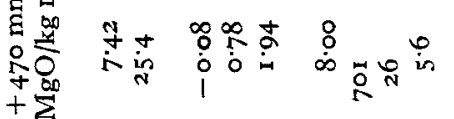

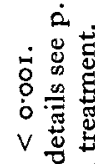

R.

$* \dot{0}$

出吕

$\wedge$ 跣

2,5

$\wedge .9$ 壱

○苛 छ

* 马

记 월

$\wedge$ 更

$R \cdot$

ड

ह

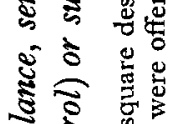

उ

过

ㅎํำ

उ $\frac{8}{5}$

ฐิ

홓

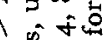

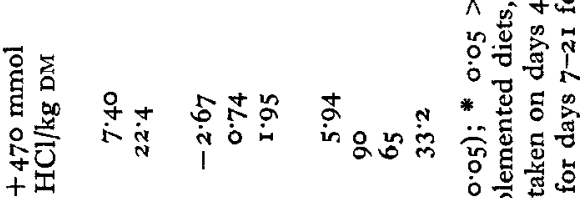

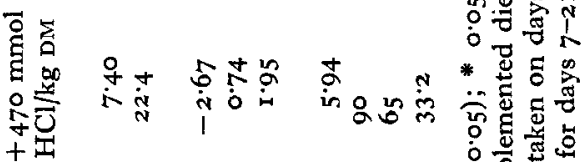

$\wedge$ 言号电

옹

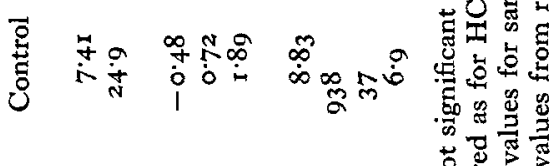

ธิ

$\star$ के

논

ปั

क.

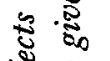

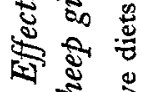

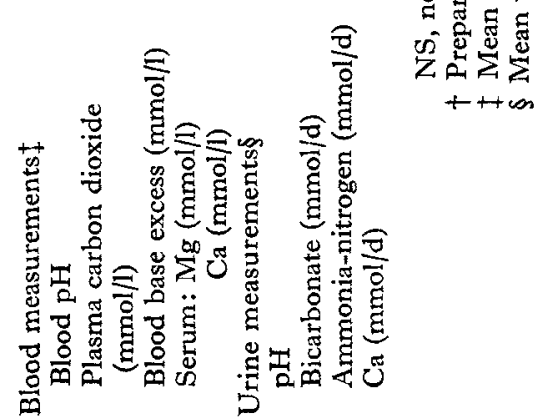

ले है 
Vol. $34 \quad \mathrm{MgO}$ as a neutralizing agent for dietary $\mathrm{HCl}$

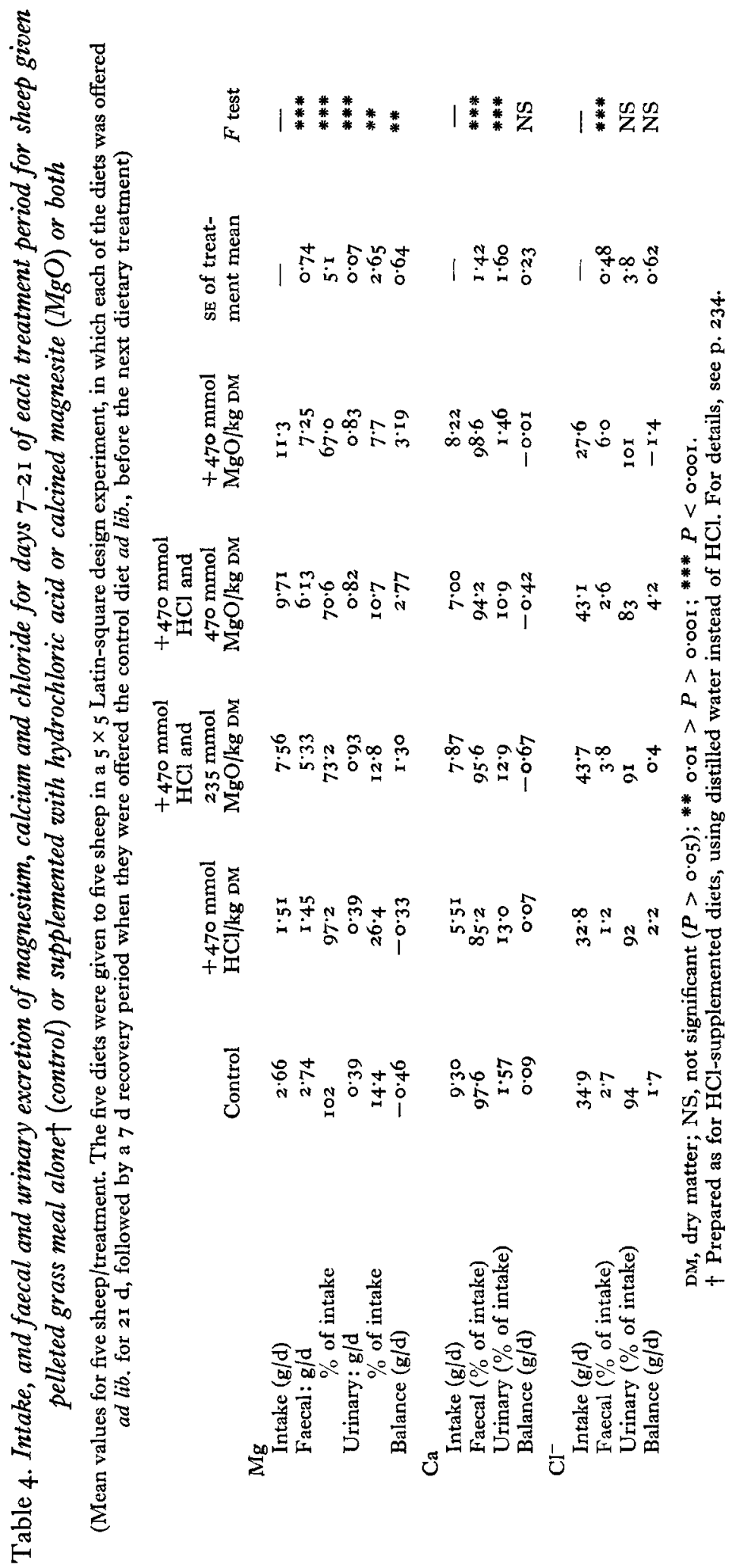


the intake, while excretion in the urine accounted for about $10 \%$ of the intake, resulting in a positive balance. $\mathrm{HCl}$ supplementation had no apparent effect on the metabolism of the supplementary Mg.

The excretion of $\mathrm{Mg}$ during the first $7 \mathrm{~d}$ of each treatment period and during the $7 \mathrm{~d}$ recovery period was also studied. For the $\mathrm{MgO}$-supplemented diets the increase in both faecal and urinary excretion of $\mathrm{Mg}$ occurred within about $4 \mathrm{~d}$ of the introduction of the supplement. During the recovery period following the $\mathrm{MgO}$-supplemented diets, $\mathrm{Mg}$ excretion in urine and faeces decreased to the control level within about 2 and $4 \mathrm{~d}$ respectively. In the absence of supplementary $\mathrm{MgO}$ the excretion of $\mathrm{Mg}$ in the urine and faeces was fairly uniform throughout the period studied.

Solubility of $\mathrm{Mg}$ in rumen fluid and faeces. The solubility of $\mathrm{Mg}$ in rumen fluid was measured in samples taken at 14.00 hours from two sheep for each treatment. The mean concentration of $\mathrm{Mg}$ was approximately similar for the control and $\mathrm{HCl}$ supplemented diets $(62 \mathrm{mg} / \mathrm{l})$. The concentration was increased up to 3 -fold by $\mathrm{MgO}$ supplementation; the treatment effect was significant $(P<0.01)$. However, the proportion which was either water-soluble or acid-soluble was not significantly affected by treatment, and was about 90 and $100 \%$ respectively. In faeces collected on days 7-2I from five sheep/treatment, the mean $\mathrm{Mg}$ concentration was increased significantly $(P<0.01)$ by $\mathrm{MgO}$ supplementation, values were 2- to 3 -fold those for the diet containing no supplementary $\mathrm{MgO}$. However, as for rumen fluid, the proportion of water-soluble and acid-soluble $\mathrm{Mg}$ was not significantly affected by treatment, averaging 30 and $86 \%$ respectively.

Intake, excretion and balance of $\mathrm{Ca}$. With the control diet, approximately $98 \%$ of dietary $\mathrm{Ca}$ was excreted in faeces and $\mathrm{r} .5 \%$ in urine (Table 4 ). The diet containing $\mathrm{MgO}$ alone did not affect this pattern. The $\mathrm{HCl}$-supplemented diet (without $\mathrm{MgO}$ ) increased the urinary Ca level to $\mathrm{I} 3 \%$ of intake and reduced the faecal Ca level to $85 \%$ of intake. $\mathrm{MgO}$ supplementation of diets containing $\mathrm{HCl}$ did not result in a decrease in the high output of urinary $\mathrm{Ca}$ but caused, however, an increase in faecal excretion of $\mathrm{Ca}$ to approximately $95 \%$ of the control value and, therefore, resulted in a negative balance of $\mathrm{Ca}$.

Intake, excretion and balance of $\mathrm{Cl}^{-}$. As the $\mathrm{Cl}^{-}$content of the basal pelleted grass meal was high, intake of $\mathrm{Cl}^{-}$was not very substantially increased by $\mathrm{HCl}$ supplementation (Table 4). The excretion in urine and the balance of $\mathrm{Cl}^{-}$were not significantly affected by treatment $(P>0.05) . \mathrm{Cl}^{-}$excretion in faeces as a percentage of intake was decreased by $\mathrm{HCl}$ supplementation alone but was increased by $\mathrm{MgO}$ supplementation.

\section{DISCUSSION}

The effect of $\mathrm{HCl}$ supplementation on voluntary food intake of the sheep in this experiment was of the same order as that caused by the same level of $\mathrm{HCl}$ supplementation in a previous experiment (L'Estrange \& McNamara, I975). MgO added to the $\mathrm{HCl}$-supplemented diet was more effective in preventing the decrease in food intake when it was added at a level equivalent to that of $\mathrm{HCl}$ than when it was added at twice that level. The finding that when given alone the high level of MgO supple- 
mentation reduced the intake of the pelleted grass meal probably explains this effect.

The extent of metabolic acidosis caused by $\mathrm{HCl}$ supplementation alone was also of the same order as that obtained in a previous experiment, using a similar level of supplementation (L'Estrange \& McNamara, 1975). MgO supplementation, surprisingly, was not effective in restoring blood acid-base status and urine acid-base excretion of the animals, and it proved much less efficient in counteracting acidosis in this study, than either $\mathrm{NaHCO}_{3}$ or limestone when these were used as neutralizing agents for silage which was preserved with mineral acids and fed to cattle (King, I943).

The low efficiency of $\mathrm{MgO}$ in countering acidosis may be accounted for by its low availability. Supplementation with $\mathrm{HCl}$ alone caused only a slight decrease in rumen fluid $\mathrm{pH}$, as previously reported by L'Estrange \& Murphy (1972) and L'Estrange \& McNamara (1975), and $\mathrm{MgO}$ supplementation also had very little effect on the $\mathrm{pH}$ of rumen fluid, in agreement with results obtained by Emery et al. (1965) for the dairy cow. It may be concluded, therefore, that the increase in food intake obtained with the $\mathrm{HCl}$-treated diet when these were supplemented with $\mathrm{MgO}$ resulted mainly from the effect of $\mathrm{MgO}$ on the $\mathrm{pH}$ of the $\mathrm{HCl}$-treated diet. This is further evidence that the adverse effect of dietary $\mathrm{HCl}$ on food intake of sheep can be accounted for mainly by reduced palatability of the diet associated with low dietary $\mathrm{pH}$, rather than by a disturbance of acid-base metabolism (L'Estrange \& McNamara, 1975).

The increase in organic matter digestibility associated with $\mathrm{HCl}$ supplementation of the pelleted grass meal is in agreement with previous results (L'Estrange \& Murphy, 1972). It was probably a result of the lower DM intake for this treatment as $\mathrm{MgO}$ supplementation of the $\mathrm{HCl}$-treated diet, while increasing DM intake, resulted in a decrease in organic matter digestibility. It has previously been reported that $\mathrm{MgO}$ supplementation of the diet does not adversely affect DM digestibility in cattle (Moore, Fontenot \& Tucker, 1971).

The effects of the high level of MgO supplementation used in this experiment are of interest also in relation to the widespread feeding of this material to cattle and sheep to prevent hypomagnesaemic tetany. The amount provided at the high level of supplementation used in our study was somewhat higher than that generally recommended for sheep, which is approximately $4^{\cdot 5-9} \circ \mathrm{g} \mathrm{Mg} / \mathrm{sheep}$ per $\mathrm{d}$. In a previous study (Black, 1966), it was found that the addition of $5.3 \mathrm{~kg} \mathrm{MgO} / \mathrm{ton}$ fresh herbage before ensilage, which raised the $\mathrm{Mg}$ content of the DM to $13.1 \mathrm{~g} / \mathrm{kg}$, caused severe scouring in sheep. In this experiment, the level of $\mathrm{Mg}$ in the DM for the high-MgO treatments was $10.9 \mathrm{~g} / \mathrm{kg}$, which, although it increased the moisture content of faeces, did not cause scouring problems, probably because dried-grass meal rather than silage was the basal diet. The proportion of the supplementary $\mathrm{Mg}$ that was excreted in urine was similar to that obtained by Black (1966) for $\mathrm{MgO}$ supplementation of silage at similar levels. In this experiment, the availability of $\mathrm{Mg}$ from the basal diet as well as from the supplementary $\mathrm{MgO}$ was low, although there was a very high proportion of water-soluble $\mathrm{Mg}$ in the rumen. In view of the recent reports that the reticulo-rumen is the most important site for the absorption of $\mathrm{Mg}$ in the ruminant (Rogers \& Van'T Klooster, I969; Strachan \& Rook, 1974), these results indicate that 
the low availability of $\mathrm{Mg}$ to ruminants given grass-based diets is due to factors affecting its transport across the rumen wall rather than its solubility in rumen fluid.

The increase in urinary $\mathrm{Ca}$ excretion caused by $\mathrm{HCl}$ supplementation alone was similar to that previously reported for sheep given diets supplemented with mineral acids or their acid salts (L'Estrange, 1970; L'Estrange \& Murphy, 1972). In this experiment, the increase in urinary $\mathrm{Ca}$ excretion was accompanied by a decrease in faecal $\mathrm{Ca}$ excretion and no change in the balance of $\mathrm{Ca}$, whereas in the previous experiment (L'Estrange \& Murphy, 1972) faecal Ca was not reduced and its balance was accordingly changed. In this experiment, when $\mathrm{MgO}$ was added to the diet together with $\mathrm{HCl}$, urinary $\mathrm{Ca}$ remained high but the percentage excreted in faeces was not reduced, and the balance of $\mathrm{Ca}$ in this instance was changed. In the literature there is general agreement that mineral acid-loading of animals leads to increased $\mathrm{Ca}$ excretion in urine, but whether this results from increased absorption of $\mathrm{Ca}$ from the intestine or from an increase in resorption of $\mathrm{Ca}$ from bone is not clear (Braithwaite, I972). The results here indicate that dietary factors such as the level of $\mathrm{Mg}$ in the diet may influence whether acid-loading leads to increased absorption from the intestine or to increased resorption from bone.

Over all, it may be concluded from this experiment that $\mathrm{MgO}$ could only be used effectively as a neutralizing agent for silage preserved with mineral acids if it was thoroughly mixed into the silage before feeding, at a level approximately equivalent to that of the mineral acid added.

The authors thank Mr S. Dillon, Mrs A. O'Brien and Miss K. McCormack for skilled technical assistance.

\section{REFEREN CES}

Black, W. J. M. (1966). Proc. Ioth int. Grassld Congr. no. 48.

Braithwaite, G. D. (1972). Br. F. Nutr, 27, 20 I.

Brouwer, E. (1935). Tierernährung 7, r.

Emery, R. S., Brown, L. D. \& Bell, J. W. (1965). F. Dairy Sci. 48, 1647.

King, W. A. (1943). F. Dairy Sci. 26, 975.

Lepard, O. L., Page, E., Maynard, L. A., Rasmussen, R. A. \& Savage, E. S. (1940). F. Dairy Sci. 23, IOI 3 .

L'Estrange, J. L. (1970). Ir. \%. agric. Res. 9, г6г.

L'Estrange, J. L. \& McNamara, T. (1975). Br. F. Nutr. 34, 221.

L'Estrange, J. L. \& Murphy, F. (1972). Br. F. Nutr. 28, I.

Mollgaard, H. \& Thorbek, G. (1938). Tierernährung ro, 105.

Moore, W. F., Fontenot, J. P. \& 'Tucker, R. E. (I97 I). F. Dairy Sci. 34, 502.

Rogers, P. A. M. \& Van'T Klooster, A. Th. (1969). Meded. LandbHoogesch. Wageningen $11,26$.

Strachan, N. H. \& Rook, J. A. F. (I 974). Proc. Nutr. Soc. 34, I 1 A.

Thomas, J. W. \& Emery, R. S. (1966). Y. Dairy Sci. 52, 60. 